\title{
MODUL KIMIA BERBASIS TRIPLECHEM UNTUK MENINGKATKAN MODEL MENTAL PESERTA DIDIK
}

\section{Gusti Ayu Karla Komala Dewi1 ${ }^{*}$, I Wayan Suja², A. A. I. A. Rai Sudiatmika ${ }^{3}$}

1,2,3 Program Studi S2 Pendidikan IPA Pasca Sarjana Universitas Pendidikan Ganesha

*Corresponding Author: karla02september@gmail.com

\section{A B S T R A K}

\section{ARTICLE INFO}

Article history:

Received July 18, 2021

Revised July 20, 2021

Accepted September 11, 2021

Available online October 25, 2021

Kata Kunci:

Miskonsepsi, Kesetimbangan

Kimia, Strategi PDEODE

Keywords:

Media Padlet, Phet

Simulation

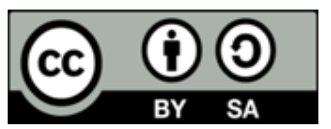

This is an open access article under the CC BY-SA license.

Copyright $(\subseteq 2021$ by Author. Published by Universitas Pendidikan Ganesha.

\begin{abstract}
Pemahaman peserta didik terhadap aspek makroskopis, submikroskopis, dan simbolik yang tidak utuh dalam pelajaran kimia membuat penulis mengembangkan modul kimia berbasis TripleChem yang valid, praktis, dan efektif untuk meningkatkan model mental peserta didik. Desain penelitian ini menggunakan model 4D yang dikembangkan oleh Thiagarajan et al. (1974), meliputi define, design, develop, disseminate. Subjek penelitian ini adalah modul kimia berbasis TripleChem, sedangkan objek penelitiannya adalah validitas, kepraktisan, dan keefektifan modul ditinjau dari model mental peserta didik. Validitas isi dan konstruk, bahasa, serta kegrafikaan berturut-turut tergolong sangat valid, valid, dan sangat valid. Kepraktisan berdasarkan hasil uji keterbacaan semua modul tergolong sangat praktis dan kepraktisan berdasarkan keterlaksanaan penggunaan modul dalam pembelajaran tergolong sangat praktis. Rerata skor N-gain model mental siswa kelas XI MIPA 1 dan XI MIPA 5 secara berturut-turut sebesar 0,73 dan 0,74 , termasuk kategori tinggi. Persentase model mental ilmiah (model konseptual) di kelas XI MIPA 1 naik sebesar $59,71 \%$ dari $10,00 \%$ menjadi $69,71 \%$, dan di kelas XI MIPA 5 naik sebesar $50,88 \%$ dari $6,16 \%$ menjadi $57,06 \%$. Hasil tersebut menunjukkan modul kimia berbasis TripleChem sudah valid, praktis dan efektif. Implikasi penelitian ini diharapkan dapat membantu guru dalam meningkatkan mental perserta didik melalui modul yang dikembangkan.
\end{abstract}

\section{A B S T R A C T}

Students' understanding of macroscopic, submicroscopic, and symbolic aspects that are not intact in chemistry lessons makes the authors develop a valid, practical, and effective TripleChem-based chemistry module to improve students' mental models. The design of this study uses a $4 D$ model developed by Thiagarajan et al. (1974), including define, design, develop, disseminate. The subject of this research is the TripleChem-based chemistry module, while the object of the research is the validity, practicality, and effectiveness of the module in terms of the students' mental models. Content and construct validity, language, and graphics are classified as very valid, valid, and very valid, respectively. Practicality based on the results of the readability test of all modules is classified as very practical and practicality based on the implementation of using modules in learning is classified as very practical. The average N-gain score of the students' mental model class XI MIPA 1 and XI MIPA 5 were 0.73 and 0.74 , respectively, including the high category. The percentage of scientific mental models (conceptual models) in class XI MIPA 1 increased by $59.71 \%$ from $10.00 \%$ to $69.71 \%$, and in grade XI MIPA 5 increased by 50.88\% from $6.16 \%$ to $57,06 \%$. These results indicate that the TripleChem-based chemistry module is valid, practical and effective. The implications of this research are expected to be able to assist teachers in improving the mentality of students through the developed modules.

\section{PENDAHULUAN}

Kimia merupakan salah satu ilmu pengetahuan yang mempelajari tentang gejala alam dengan mengambil materi sebagai objek (Andani \& Yulian, 2018; Mujakir \& Rusydi, 2019). Ilmu ini khusus membahas tentang struktur, komposisi zat, perubahan materi, dan energi yang menyertai perubahan 
tersebut. proses pembelajaran di kelas adalah salah satu tahap yang sangat menentukan keberhasilan belajar siswa (Gazali \& Yusmaita, 2018; Pandaleke et al., 2020). Guru sebagai salah satu mediator dan komponen pengajaran mempunyai peranan penting dalam mencapai tujuan pembelajaran dan sangat menentukan keberhasilan proses pendidikan, karena guru terlibat langsung di dalamnya. Ilmu kimia memiliki karakteristik yang berbeda dari cabang ilmu pengetahuan alam lainnya. Karakteristik ilmu kimia bersifat kompleks dan abstrak. Keabstrakan konsep kimia tersebut berpotensi menyebabkan kesulitan bagi peserta didik untuk mempelajarinya (Ristiyani \& Bahriah, E., 2016). Namun selama ini, pembelajaran kimia yang terjadi belum menekankan pemahaman ketiga level kimia tersebut. Guru-guru cenderung hanya menjelaskan level makroskopis dan simbolik saja, sedangkan level submikroskopisnya jarang dipaparkan (Iqbal \& Tarigan, 2019; Wahdan et al., 2017). Kondisi itu menyebabkan pemahaman peserta didik tentang konsep-konsep kimia lebih didominasi oleh pemahaman pada level makroskopis dan simbolik, serta lemah pada pemahaman level submikroskopis. Akibatnya, model mental kimia peserta didik menjadi tidak utuh (Suja et al., 2017; Syarifuddin \& Dwiningsih, 2020). Bahkan, peserta didik sering mengalami miskonsepsi akibat rendahnya pemahaman terhadap ketiga aspek kimia tersebut (Apriadi et al., 2018). Berdasarkan observasi terhadap modul yang dipergunakan guru kimia di SMA se-Kota Denpasar, peneliti memperoleh hasil sebagai berikut. Pertama, materi di dalam modul belum mengaitkan tiga level representasi kimia secara utuh. Kedua, format modul-modul tersebut sangat kaku dan tidak sesuai dengan karakteristik minimal sebuah modul yang disarankan oleh Depdiknas. Hal ini sesuai dengan penelitian Modul yang sudah ada belum memiliki format yang seragam dan bahkan beberapa modul susah dipahami sehingga membingungkan saat kegiatan pembelajaran. Atas dasar itu, keberadaan modul yang sesuai dengan format standar dan memuat interkoneksi ketiga level kimia secara utuh sangat diperlukan dalam pembelajaran kimia (Asmiyunda et al., 2018; Hamdi, Halim \& Pontas, 2015). Permasalahan tersebut perlu diatasi agar tidak memberikan dampak buruk bagi peserta didik.

Solusi yang dilakukan untu meningkatkan model mental peserta didik melalui pelaksanaan pembelajaran kimia. Kegiatan tersebut dapat dilakukan dengan menerapkan model-model pembelajaran yang khusus dikembangkan untuk membelajarkan konsep-konsep kimia (specific model). Konsep-konsep yang diajarkan harus menyertakan ketiga representasi level kimia secara utuh. Salah satu model pembelajaran yang dapat membantu membangun model mental peserta didik adalah model pembelajaran TripleChem (Suja et al., 2017). Model pembelajaran TripleChem memiliki kekhasan ditinjau dari sintaks pembelajarannya dan layak diterapkan untuk pembelajaran kimia. Model pembelajaran tersebut tergolong sangat valid dan praktis diterapkan dalam pembelajaran di kelas (Suja et al., 2017). Hasil uji coba skala kecil dan luas, menunjukkan model pembelajaran TripleChem efektif diterapkan untuk meningkatkan kinerja, membangun model mental kimia, meningkatkan keterampilan berpikir kritis dan kreatif, serta mengembangkan sikap personal dan sosial mahasiswa (Ariani, 2020). Berdasarkan pemaparan di atas, memberikan alternatif rekomendasi dengan mengembangkan modul belajar secara sinergis menggunakan model pembelajaran TripleChem pada materi Kimia Kelas XI Semester 2. Pemilihan materi Kimia Kelas XI SMA semester 2 dikarenakan materi-materi kelas XI tergolong sulit bagi sebagian peserta didik dan sering menimbulkan terjadinya miskonsepsi. Beberapa temuan menyatakan terjadi miskonsepsi dalam bentuk konsep teoritik, korelasional, dan klasifikasional pada materi termokimia (Apriadi et al., 2018; Mentari et al., 2017). Penelitian-penelitian yang sudah dilakukan dan memperoleh hasil yang bagus sesuai dengan tuntutan pendidikan abad ke-21 belum diimbangi dengan adanya bahan ajar yang mampu diterapkan dalam proses pembelajarannya. Di sisi lain, model pembelajaran TripleChem terbukti efektif digunakan untuk mengajarkan konsep kimia karena tahapan pembelajarannya mencakup tiga level kimia dan interkoneksinya (Suja et al., 2017) Dengan demikian, pengembangan modul ini merupakan kelanjutan dan bentuk operasionalisasi implementasi model pembelajaran TripleChem di kelas dengan tujuan untuk meningkatkan model mental peserta didik. Sehingga tujuan penelitian ini untuk menciptakan modul kimia berbasis triplechem untuk meningkatkan model mental peserta didik. Adanya modul ini diharapkan dapat meningkatkan model mental peserta didik.

\section{METODE}

Penelitian ini merupakan Penelitian dan Pengembangan (Research and Development) menggunakan model 4D yang dikembangkan oleh Thiagarajan et al. (1974), terdiri atas tahap pendefinisian (Define), tahap perancangan (Design), tahap pengembangan (Develop), dan tahap diseminasi (Disseminate). Modul pembelajaran kimia berbasis TripleChem dikembangkan sesuai dengan prosedur penelitian dan pengembangan (R \& D) Thiagarajan, et al. (1974) untuk menghasilkan modul yang valid, praktis, dan efektif berbasis TripleChem. Tahap Define bertujuan untuk mengumpulkan berbagai informasi 
yang berkaitan dengan produk yang dikembangkan. Tahap design (perencanaan) bertujuan untuk merencanakan atau merancang kerangka isi dan garis besar dari suatu produk yang dikembangkan, yaitu modul kimia berbasis TripleChem. Tahap develop (pengembangan) dikelompokkan dalam dua kegiatan, yaitu expert appraisal, merupakan kegiatan untuk memvalidasi atau menilai kelayakan rancangan produk yang dikembangkan oleh peneliti, dan developmental testing merupakan kegiatan uji coba rancangan produk pada peserta didik. Teknik pengumpulan data mulai dari pemberian angket (kuesioner), observasi, dan pemberian tes. Teknik analisis data dimulai dengan menelaah seluruh data yang tersedia dari berbagai sumber setelah melakukan penelitian dengan observasi, interview, angket, dan dokumentasi (Sutrisno, 2004). Validitas isi dan konstruk modul berbasis TripleChem menggunakan analisis berdasarkan Gregory (2000), yang tujuannya untuk melihat kesepakatan dari 2 ahli dalam menilai keseluruhan konten modul. Kriteria validitas berdasarkan rumus Gregory ditampilkan pada Tabel 1.

Tabel 1. Kriteria Validitas Berdasarkan Rumus Gregory

\begin{tabular}{cc}
\hline Rentang nilai & Kriteria validitas isi \\
\hline $0,8-1$ & Validitas sangat tinggi \\
$0,6-0,79$ & Validitas tinggi \\
$0,4-0,59$ & Validitas sedang \\
$0,2-0,39$ & Validitas rendah \\
$0,0-0,19$ & Validitas sangat rendah \\
\hline
\end{tabular}

(Retnawati, 2015)

Konsistensi atau kesesuaian penilaian oleh dua orang ahli menggunakan percentage of agreement. Analisis percentage of agreement terhadap kelayakan modul berbasis TripleChem dapat ditetapkan dengan menggunakan rumus sebagai berikut (Borich, 1994). Batas bawah percentage of agreement yang digunakan untuk suatu penilaian yang baik yaitu sebesar $70 \%$ sesuai Tabel 2. Validasi ahli kegrafikaan, bahasa, dan soal melibatkan masing-masing 1 orang ahli di bidangnya. Data yang diperoleh dari tahap perencanaan dan pembuatan produk dianalisis karakteristiknya dengan mendeskripsikan ciri dari produk tersebut. Data dari uji validitas kegrafikaan dan bahasa berupa data kualitatif dalam kategori sangat baik (SB), baik (B), cukup (C), dan kurang (K) terhadap aspek-aspek modul berbasis TripleChem dan masukanmasukan dari validator. Kriteria validitas disajikan pada Tabel 3. Aspek kepraktisan ditinjau dari keterbacaan dan keterlaksanaan dalam pembelajaran. Hasil uji keterbacaan dan keterlaksanaan dalam pembelajaran berupa penilaian dalam skala dianalisis untuk menentukan skor rata-rata yang selanjutnya dikonversi ke dalam bentuk tabel sesuai dengan kategori yang diperoleh, seperti pada Tabel 4.

Tabel 2. Kriteria Percentage of Agreement

\begin{tabular}{ccc}
\hline No. & Rentang Nilai Percentage of agreement & Kriteria \\
\hline 1. & $\geq 70$ & Baik \\
2. & $<70$ & Kurang Baik \\
\hline
\end{tabular}

(Linn, 1989)

Tabel 3. Kriteria Validitas Kegrafikaan, Bahasa pada Modul, dan Soal

\begin{tabular}{ccc}
\hline No. & Skor (\%) & Kriteria Validitas \\
\hline 1 & $85,01-100,00$ & Sangat valid \\
2 & $70,01-85,00$ & Valid \\
3 & $50,01-70,00$ & Kurang valid \\
4 & $01,00-50,00$ & Tidak valid \\
\hline
\end{tabular}

Tabel 4. Kriteria Kepraktisan Ditinjau dari Keterbacaan dalam Skala 5.

\begin{tabular}{cc}
\hline Interval Skor & Kategori \\
\hline $4,0<\bar{\chi} \leq 5,0$ & Sangat praktis \\
$3,0<\bar{\chi} \leq 4,0$ & Praktis \\
$2,0<\bar{\chi} \leq 3,0$ & Cukup praktis \\
$1,0<\bar{\chi} \leq 2,0$ & Tidak praktis \\
$0,0 \leq \bar{\chi} \leq 1,0$ & Sangat tidak praktis \\
\hline
\end{tabular}


Uji efektivitas modul sebagai produk dalam penelitian ini menggunakan rancangan preexperiment One Group Pretest-Posttest Design. Kelompok eksperimen diberikan pretest model mental, kemudian diberikan perlakuan pembelajaran dengan menggunakan modul berbasis TripleChem dan pada tahap akhir diberikan posttest model mental. Efektivitas modul berbasis TripleChem pada penelitian dan pengembangan ini dilihat dari penilaian model mental peserta didik. Penilaian menggunakan lembar tes di awal pembelajaran (pretest) dan di akhir pembelajaran (posttest). Data pretest dan posttest yang diperoleh dianalisis dengan skor gain. Gain score (g) merupakan metode yang dirumuskan oleh Hake (1999). Kriteria tingkat perolehan gain score ternormalisasi dikategorikan dalam tiga kategori ditampilkan pada Tabel 5. Lembar tes model mental yang telah diberikan rubrik penilaian dianalisis kembali berdasarkan tiga aspek, meliputi aspek makroskopis, submikroskopis, dan simbolik. Diadaptasi dari Sendur et al. (2010), kesimpulan model mental peserta didik berdasarkan hasil tes di tiap-tiap soal ditampilkan pada Tabel 6.

Tabel 5. Kriteria Gain Score Ternormalisasi.

\begin{tabular}{cc}
\hline Interval & Kategori N-gain \\
\hline$(\mathrm{g})>0,7$ & Tinggi \\
$0,7 \geq(\mathrm{g}) \geq 0,3$ & Sedang \\
$(\mathrm{g})<0,3$ & Rendah \\
\hline
\end{tabular}

Tabel 6. Profil Model Mental Peserta Didik.

(Hake, 1999)

\begin{tabular}{ccc}
\hline No. & Nilai tiap butir soal & Kesimpulan \\
\hline 1. & 0 & Miskonsepsi \\
2. & $1-2$ & Benar Sebagian \\
3. & 3 & Benar secara keilmuan/Ilmiah/ konseptual \\
\hline
\end{tabular}

\section{HASIL DAN PEMBAHASAN}

Hasil

Modul sesuai dengan data pada tahap define di atas menunjukkan bahwa diperlukan modul sebagai penunjang pembelajaran mandiri yang mampu mengakomodasi representasi level makroskopis, submikroskopis, dan simbolik peserta didik.Karakteristik modul kimia berbasis TripleChem yang dikembangkan mengoperasionalisasikan sintaks model TripleChem, meliputi tahap: observing, reasoning, modeling, explanating, dan applicating.

Tahap observing ditujukan untuk membentuk model mental peserta didik tentang level makroskopis kimia. Level makroskopis kimia menyangkut sifat fisika dan kimia zat, yang dapat diamati dan dipersepsikan dengan panca indera (sensory level). Tahap reasoning ditujukan untuk membentuk model mental peserta didik tentang level submikroskopis kimia. Model mental submikroskopis bermanfaat untuk menjelaskan fenomena makroskopis berdasarkan kajian tingkat molekuler. Tahap modeling ditujukan untuk memahami level simbolik kimia dengan memvisualisasikan struktur molekulnya yang tidak kasat mata. Tahap modeling menjadi wahana untuk melatih berpikir kritis dan kreatif. Tahap ini dilengkapi dengan penggunaan analogi untuk membantu peserta didik dalam memahami konsep-konsep abstrak dan mempermudah menyimpan informasi dalam memori jangka panjang. Tahap explanating ditujukan untuk membangun model mental kimia peserta didik secara utuh menyangkut interkoneksi tiga level kimia melalui proses penemuan atau penerimaan informasi dari sumber terpercaya. Aspek penting untuk merumuskan eksplanasi tergantung pada kemampuan peserta didik mentransfer satu level kimia ke level lainnya didukung dengan kemampuan berpikir kritis dan kreatif. Tahap applicating ditujukan untuk menguji kebenaran model mental peserta didik tentang tiga level kimia dan interkoneksinya, yang terbangun melalui empat tahap pembelajaran sebelumnya. Pada tahap applicating peserta didik juga memiliki kesempatan untuk menerapkan berpikir kritis dan kreatifnya dalam memecahkan masalah. Modul kimia berbasis TripleChem yang dikembangkan sebelum diujicobakan di kelas harus melalui uji validasi ahli. Validasi modul kimia berbasis TripleChem yang dikembangkan meliputi validasi isi dan konstruk, validasi kegrafikaan, serta validasi bahasa. Secara keseluruhan modul kimia berbasis TripleChem yang dihasilkan pada materi asam basa, larutan penyangga, hidrolisis garam, dan titrasi asam basa memiliki validitas isi sangat tinggi. Percentage of agreement masing-masing modul berdasarkan kemiripan pendapat tim ahli juga tergolong baik. Nilai percentage of 
agreement tersebut mengindikasikan bahwa penilaian kedua validator terhadap isi dan konstruk modul kimia berbasis TripleChem bersifat reliabel. Keempat modul tersebut juga memiliki validitas kegrafikaan dan bahasa yang masing-masing tergolong tinggi dan sangat tinggi sehingga layak untuk dilanjutkan pada tahap pengembangan berikutnya. Validitas produk ditinjau dari validitas isi dan percentage of agreement. Modul yang dikembangkan divalidasi oleh 2 (dua) orang ahli materi, 1 (satu) ahli kegrafikaan, dan 1 (satu) ahli bahasa dengan hasil ditampilkan pada Tabel 8. Uji kepraktisan berdasarkan keterbacaan diperoleh hasil seperti ditampilkan pada Tabel 9. Nilai rata-rata kepraktisan penerapan modul dalam pembelajaran adalah sebesar 4,36 dengan kategori sangat praktis. Keefektifan penerapan modul ditinjau dari pemberian soal model mental memperoleh hasil ditampilkan pada Tabel 10.

Tabel 7. Hasil Vaslidasi Modul

\begin{tabular}{lcccccc}
\hline \multicolumn{1}{c}{ Modul } & \multicolumn{2}{c}{ Isi dan konstruk } & \multicolumn{2}{c}{ Kegrafikaan } & & \multicolumn{2}{c}{ Bahasa } \\
& Nilai & Kriteria & Nilai & Kriteria & Nilai & Kriteria \\
& 1,00 & Sangat valid & 0,75 & Valid & 0,92 & Sangat valid \\
& 1,00 & Sangat valid & 0,75 & Valid & 0,92 & Sangat valid \\
Asam basa & 1,00 & Sangat valid & 0,75 & Valid & 0,92 & Sangat valid \\
Larutan penyangga & 1,00 & Sangat valid & 0,75 & Valid & 0,92 & Sangat valid \\
Hidrolisis garam & & & & & & \\
\hline
\end{tabular}

Tabel 8. Hasil Uji Keterbacaan.

\begin{tabular}{lcccc}
\hline \multicolumn{1}{c}{ Modul } & \multicolumn{2}{c}{ Kepraktisan } & \multicolumn{2}{c}{ Percentage of agreement } \\
& Nilai & Kriteria & Guru (\%) & Peserta didik (\%) \\
\hline Asam basa & 4,33 & Sangat praktis & 97,25 & 92,75 \\
Larutan penyangga & 4,28 & Sangat praktis & 99,07 & 93,66 \\
Hidrolisis garam & 4,40 & Sangat praktis & 96,83 & 94,29 \\
Titrasi asam basa & 4,31 & Sangat praktis & 98,15 & 93,72 \\
\hline
\end{tabular}

Tabel 9. Skor N-gain Kelas XI MIPA 1 dan XI MIPA 5.

\begin{tabular}{|c|c|c|}
\hline Kelas & $\begin{array}{l}\text { Soal model mental } \\
\text { Nilai }\end{array}$ & Kriteria \\
\hline XI MIPA 1 & 0,72 & Tinggi \\
\hline XI MIPA 5 & 0,74 & Tinggi \\
\hline
\end{tabular}

\section{Pembahasan}

Berdasarkan hasil penelitian yang disajikan, karakteristik modul kimia berbasis TripleChem yang dihasilkan, validitas, kepraktisan, dan keefektifan modul kimia berbasis TripleChem yang dihasilkan ditinjau dari model mental peserta didik. Kepraktisan modul kimia berbasis TripleChem yang dikembangkan dimulai dari uji keterbacaan oleh 3 orang guru kimia dan 9 peserta didik kelas XII MIPA. Prosedur pada tahap-tahap pengembangan bahan ajar telah dilakukan dan menghasilkan modul sebagai bahan ajar yang valid, praktis dan efektif dalam pembelajaran sesuai dengan tujuan penelitian. Dengan menggunakan bahan ajar berbentuk modul ini, siswa lebih mudah mengikuti pembelajaran sehingga proses pembelajaran dapat berlangsung secara efektif. Keefektifan modul ini dapat dilihat dari hasil belajar siswa setelah menggunakan modul. Pembelajaran dengan menggunakan modul ini dapat mempersingkat waktu belajar dan dapat membuat siswa belajar mandiri, siswa dapat mempelajari terlebih Kepraktisan perangkat pembelajaran sangat penting diketahui sebelum diterapkan di dalam kelas. Perangkat pembelajaran yang praktis mampu digunakan dalam pembelajaran dan dapat terlaksana dengan baik (Kulagina et al., 2021; Rahmawati, 2015). Hasil uji kepraktisan modul asam basa, larutan penyangga, hidrolisis garam, dan titrasi asam basa ditinjau dari keterbacaan tergolong sangat praktis. Poin-poin yang dinilai hampir semua memperoleh hasil maksimal 5, yang mengindikasikan sangat praktisnya modul asam basa, larutan penyangga, hidrolisis garam, dan titrasi asam basa yang dikembangkan peneliti. Percentage of agreement penilaian terhadap modul asam basa, larutan penyangga, hidrolisis garam, dan titrasi asam basa dikategorikan baik. Hal itu menunjukkan bahwa guru dan peserta didik memiliki persepsi dan pandangan yang hampir sama terhadap isi dari lembar penilaian terhadap modul kimia berbasis TripleChem yang dikembangkan. Hasil uji kepraktisan modul berdasarkan implementasinya di kelas menunjukkan semua peserta didik sangat memahami uraian materi dan bahasa yang digunakan pada modul kimia berbasis TripleChem dalam menunjang pembelajaran. Peserta didik 
menyatakan bahwa modul kimia berbasis TripleChem sangat praktis, sistematis, dan menunjang kemandirian. Penggunaan modul kimia berbasis TripleChem efektif untuk meningkatkan model mental peserta didik, terbukti dengan terjadinya penurunan persentase model mental miskonsepsi dan benar sebagian (Suja et al., 2017). Temuan tersebut diperkuat dengan penelitian sebelumnya yang menyatakan penerapan model pembelajaran TripleChem efektif digunakan untuk membangun model mental mahasiswa calon guru kimia tentang korelasi struktur dan sifat senyawa organic (Asmiyunda et al., 2018; Rahmawati, 2015). Penerapan model pembelajaran TripleChem mampu menurunkan miskonsepsi dan model mental benar sebagaian peserta didik (Suja et al., 2017). Berdasarkan analisis terhadap keterlaksanaan pembelajaran dapat dinyatakan bahwa modul asam basa, larutan penyangga, hidrolisis garam, dan titrasi asam basa berbasis TripleChem yang dikembangkan dalam penelitian ini tergolong valid dari segi isi dan konstruk, bahasa, serta kegrafikaan. Kepraktisan dari keterbacaan dan keterlaksanaan tergolong sangat praktis. Modul yang dikembangkan tergolong efektif berdasarkan peningkatan konsep ilmiah peserta didik. Implikasi penelitian ini diharapkan dapat membantu guru dalam meningkatkan mental perserta didik melalui modul yang dikembangkan.

\section{SIMPULAN DAN SARAN}

Modul yang dikembangkan tergolong efektif berdasarkan peningkatan konsep ilmiah peserta didik. Modul ini dapat membantu siswa dalam meningkatkan mental peserta didik. Sehingga modul ini dapat digunakan guru dalam proses pembelajaran. selain itu, model pembelajaran TripleChem efektif digunakan untuk membangun model mental mahasiswa calon guru kimia.

\section{DAFTAR RUJUKAN}

Andani, D. T., \& Yulian, M. (2018). Pengembangan Bahan Ajar Electronic Book Menggunakan Software Kvisoft Flipbook Pada Materi Hukum Dasar Kimia di SMA Negeri 1 Panton Reu Aceh Barat. Jurnal IPA Dan Pembelajaran IPA, 2(1), 1 - 6. https://doi.org/10.24815/jipi.v2i1.10730.

Apriadi, N. N. S., Redhana, I. W., \& Suardana, I. N. (2018). Identifikasi Miskonsepsi Siswa Kelas X pada Topik Reaksi Redoks. Jurnal Pendidikan Kimia Indonesia, 2(2), 70-77. https://doi.org/10.23887/jpk.v2i2.16617.

Ariani, T. (2020). Analysis of Students' Critical Thinking Skills in Physics Problems. Physics Educational Journal, 3(1), 1-13. https://doi.org/10.37891/kpej.v3i1.119.

Asmiyunda, A., Guspatni, G., \& Azra, F. (2018). Pengembangan E-Modul Kesetimbangan Kimia Berbasis Pendekatan Saintifik untuk Kelas XI SMA/ MA. Jurnal Eksakta Pendidikan (JEP), 2(2), 155. https://doi.org/10.24036/jep/vol2-iss2/202.

Gazali, F., \& Yusmaita, E. (2018). Analisis Prior Knowledge Konsep Asam Basa Siswa Kelas XI SMA untuk Merancang Modul Kimia Berbasis REACT. Jurnal Eksakta Pendidikan (Jep), 2(2), 202-208. https://doi.org/10.24036/jep/vol2-iss2/249.

Hamdi, Halim, A., \& Pontas, K. (2015). Pengembangan Dan Penerapan Modul Pembelajaran Materi Teori Dasar Bentuk Muka Bumi Untuk Meningkatkan Kognitif Mahasiswa Pendidikan MIPA FKIP UNIGHA Sigli. Jurnal Pendidikan Sains Indonesia, 3(2), 22-34. http://www.jurnal.unsyiah.ac.id/JPSI/article/view/7676.

Iqbal, M., \& Tarigan, I. L. (2019). Pengaruh Model Pembelajaran Siklus Belajar 5E Menggunakan Media Animasi Terhadap Aktivitas Belajar Dan Hasil Belajar Siswa Sma Kelas Xi Pada Materi Hidrolisis Garam. J-PEK Jurnal Pembelajaran Kimia), 4(1), 31-38. https://doi.org/10.17977/um026v4i12019p031.

Kulagina, K., Leksashova, A., Bolsunovskayaa, M., \& Shirokovaa, S. (2021). Development of a Human Flow Generation Module for Testing Machine Learning Algorithms. Transportation Research Procedia, 54, 783-792. https://doi.org/10.1016/j.trpro.2021.02.134.

Mentari, L., Suardana, I. N., \& Subagia, I. W. (2017). Analisis Miskonsepsi Peserta didik SMA pada Pembelajaran Kimia untuk Materi Larutan Penyangga. Jurnal Pendidikan Kimia Undiksha, 1(1). https://doi.org/10.23887/jjpk.v1i1.3975.

Mujakir, \& Rusydi. (2019). Pembelajaran Kimia Inovatif untuk Melatih Siswa Menjelaskan Masalah. Jurnal Ilmiah Didaktika: Media Ilmiah Pendidikan Dan Pengajaran, 20(1), 38 - 57. https://doi.org/10.22373/jid.v20i1.4450.

Pandaleke, M., Munzil, \& Sumari. (2020). Pengembangan Media Pelajaran Kelas Flipped Berbasis Animasi 
untuk Meningkatkan Pemahaman Konsep Kimia. Jurnal Pendidikan: Teori, Penelitian Dan Pengembangan, 5(3), 387-394. https://doi.org/10.17977/jptpp.v5i3.13293.

Rahmawati, A. (2015). Pengembangan Modul Kimia Dasar Berbasis Multipel Level Representasi untuk Meningkatkan Kemampuan Berpikir Kritis Mahasiswa. Phenomenon: Jurnal Pendidikan MIPA, 5(2), 5-17.

Ristiyani, E., \& Bahriah, E., S. (2016). Analisis Kesulitan Belajar Kimia Peserta didik di SMAN X Kota Tangerang Selatan. Jurnal Penelitian Dan Pembelajaran IPA, 2(1), 18-29. https://doi.org/10.30870/jppi.v2i1.431.

Suja, I. W., Yuanita, L., \& Ibrahim, M. (2017). Implementation Impact Of The Triplechem Learning Model On Personal And Social Attitudes of Chemistry Prospective Teachers. Journal of Education Research and Evaluation, 1(4), 269-275. https://doi.org/10.23887/jere.v1i4.12556.

Syarifuddin, M. K., \& Dwiningsih, K. (2020). The Validity Multimedia Interactive Bases Android On Ionic Bond Mterial. JCER (Journal of Chemistry Education Research), 4(2), 63-70. https://doi.org/10.26740/jcer.v4n2.p63-70.

Wahdan, W. Z., Sulistina, O., \& Sukarianingsih, D. (2017). Analisis Kemampuan Berargumentasi Ilmiah Materi Ikatan Kimia Peserta Didik Sma, Man, Dan Perguruan Tinggi Tingkat I. J-PEK (Jurnal Pembelajaran Kimia), 2(2), 30-40. https://doi.org/10.17977/um026v2i22017p030. 